\title{
Civic Attitudes and Engagement Among Middle Eastern and North African Refugees and Immigrants in the U.S.
}

\author{
Sara Makki Alamdari
}

\begin{abstract}
Given the importance of civic engagement to the well-being of immigrants and refugees and their communities, the goal of the current study was to investigate civic attitudes among immigrants and refugees from the Middle East and North Africa (MENA). First, the researcher examined predictors of civic attitudes. Second, the mediating effect of attitudes between the potential predictors (i.e., gender, health status, English proficiency, and the U.S. length of stay) and level of civic engagement was investigated. The researcher recruited 145 respondents to complete online and paper-based surveys. Using linear regression models, the results show that health and English language proficiency significantly predict civic attitudes among this group. Attitudes also mediated between health status and level of civic engagement. This study provides some implications for social work, resettlement programs, health policies, and civic organizations that can be beneficial for the target group as well as for the host communities.
\end{abstract}

Keywords: Civic engagement; civic attitudes; refugees; immigrants; Middle East; North Africa

Civic engagement refers to the ways in which community members or people take collective action with the purpose of addressing community or public challenges and improving conditions for others (Adler \& Goggin, 2005; Checkoway, 2009). Civic activities can have a variety of forms such as volunteering, donation, group involvement, political action, community service, and media use (Gastil \& Xenos, 2010; Keeter et al., 2003; Uslaner \& Brown, 2005). Civic engagement can bring many benefits for individuals and communities. Individuals' social skills and networks can be improved as a result of being civically engaged in their communities (Chan, 2011; Hope \& Jagers, 2014; Weng \& Lee, 2016). Individuals' well-being, health, and life satisfaction can also be enhanced by civic engagement (Dabelko-Schoeny et al., 2010; Gele \& Harsløf, 2012). On a larger scale, civic engagement is beneficial in improving social and human capital, citizenship, and democracy as well as the quality of public life (Handy \& Greenspan, 2009; Makki Alamdari \& Jalaiepour, 2012; Putnam, 1995; Tucker \& Santiago, 2013). Taking into account its benefits for individuals and societies, studying civic engagement among different groups is valuable and can provide important implications for the social work profession.

In this vein, this research was interested in immigrants and refugees living in the U.S. Although refugees and immigrants leave their home country for different reasons and have different lived experiences, they still have much in common in terms of culture, religious beliefs, history, language, and some post-migration experiences such as under-employment, language barriers, and discrimination (Aroian et al., 2008). Every year, a considerable number of immigrants enter the U.S. for various reasons. In 2017, nearly 1.9 million individuals obtained lawful permanent residence, were naturalized in the U.S., or entered the U.S. as a refugee (Department of Homeland Security, 2019). Immigrants and refugees from the Middle East and North Africa




(MENA) are the particular focus of this study as they are understudied (Read, 2014; Zarpour, 2013). There are 20 countries in this region including Algeria, Bahrain, Djibouti, Egypt, Iran, Iraq, Jordan, Kuwait, Lebanon, Libya, Morocco, Oman, Qatar, Saudi Arabia, Palestine, Sudan, Syria, Tunisia, United Arab Emirates, and Yemen (Office of the High Commissioner for Human Rights [OHCHR], 2019). Almost 6\% of the world's population lives in this area (World Bank, 2019). These countries share many cultural commonalities. For example, the dominant religion is Islam (Pew Research Center, 2015) and collectivism is the more valued culture (Schwartz et al., 2010). Unfortunately, negative perceptions regarding this immigrant community are prevalent in the U.S. (Makki Alamdari, 2020; Strabac et al., 2014). Considering the rise of negative public perceptions regarding Muslims (Abu-Ras, 2013; Emami, 2018; Vergani et al., 2017), examining civic engagement among this group is imperative especially given the limited number of studies with this group (Makki Alamdari, 2017; Makki Alamdari \& Bishop, 2020).

\section{Literature Review}

Civic engagement can be examined in terms of skills, attitudes, knowledge, goals, and behavior (Crocetti et al., 2012). For the purpose of this study, the researcher was interested in examining attitudes towards civic engagement. Civic attitudes include the sense of social responsibility and commitment (i.e., a sense of duty to community), tolerance of diversity, civic pride, civic faith, and civic efficacy (i.e., belief that one is able to impact the community; Crocetti et al., 2012; Gastil \& Xenos, 2010; O'Leary, 2014).

The purpose of this study was twofold. First, the researcher examined the factors that may predict the civic attitudes among the target population. In association with civic engagement behavior such as volunteering and organizational membership, studies have examined a variety of predictors such as educational level, length of stay in the host country, health status, age, employment, family income, acculturation, gender, marital status, social networks, and identity (Chan, 2011; Handy \& Greenspan, 2009; Sundeen et al., 2009; Tucker \& Santiago, 2013; Weng \& Lee, 2016). Although these factors have not been particularly examined regarding civic attitudes, they are critical to consider. Examining all these factors was out of the scope and resources of this study. For purposes of this study, the researcher examined four factors including gender, health status, local language proficiency, and the length of stay in the host country. Health status and gender are frequently discussed and underlined as important factors in the study of immigrants and refugees (Bishop \& Makki Alamdari, 2018; Makki Alamdari et al., 2016; Sundeen et al., 2009). The last two factors-language proficiency and length of stay - are specifically relevant to the condition of immigrants and refugees.

Gender. In a study of high school students in Italy, Crocetti et al. (2012) conceptualized civic attitudes as social responsibility, and found significantly higher scores among females. Although the study by Crocetti et al. (2012) was not specific to immigrants and refugees, it was relevant because it investigated civic attitudes in regard to gender. Similarly, Emami (2018) examined about 350 Iranian diaspora in the U.S. and highlighted that women were more active than men in joining interest groups for the purposes of advocacy. Studying monetary donations among nearly 1,300 adults in Chile, Luengo Kanacri et al. (2016) reported that women were significantly more involved than men in this form of civic engagement. While their study was not 
specifically regarding immigrant or refugee population, it is an important study for examining the effect of several factors on civic engagement among a large population of adults (Luengo Kanacri et al., 2016).

Health status. Most studies in this area investigated the effects of civic engagement on health (Brown et al., 2017; Chandra et al., 2016). However, a few considered the effects of health on civic involvement, which are mainly in the Western context. For example, Ding, Berry, and O'Brien (2015) and Emerson, Hatton, Robertson, and Baines (2014) conducted secondary analyses with nationally representative samples in Australia and the UK, respectively, and found that higher levels of civic and social participation and more positive perceptions of neighborhood were predicted by higher levels of self-reported health and mental well-being. Emerson et al. (2014) also found a significant difference in membership in civic organizations between those with intellectual disabilities and non-disabled peers. Examining political participation in Wisconsin, Burden, Fletcher, Herd, Moynihan, and Jones (2017) reported cognitive and physical well-being as powerful factors influencing voting behavior.

Local language proficiency. The host country's language is a critical factor for immigrants and refugees in their civic engagement because it allows for improved communication, resilience, and integration in the new society (Pieloch et al., 2016; Voicu \& Rusu, 2012). Boyd (2009) studied immigrants in Canada and found that language skills are significantly associated with types and levels of civic engagement. Similarly, Van Londen, Phalet, and Hagendoorn (2007) examined nearly 1,200 Turkish and Moroccan immigrants in the Netherlands and reported Dutch language mastery as a significant factor contributing to political participation. Studying obstacles to civic engagement in Miami's Haitian immigrant community, Stepick, Stepick, and Kretsedemas (2001) found language difficulties as a major challenge.

Length of stay in the host country. Voicu and Rusu (2012) and Gidengil and Stolle (2009) studied immigrants in Spain and Canada and indicated the length of stay in the host country as a factor influencing immigrants' involvement in civic associations and political participation through increasing exposure to such activities. Using mixed methods, Handy and Greenspan (2009) studied immigrants in four cities of Canada and reported that established immigrants were more likely to be involved in community volunteering activities.

The second purpose of this study was to investigate the mediation effect of attitudes between the aforementioned four factors and level of civic engagement behavior. According to psychological theories, civic attitudes and behaviors can have complex reciprocal causal relationships (Crocetti et al., 2012; Gastil \& Xenos, 2010). Civic attitudes are considered as an important factor that potentially predicts level of civic engagement. This is consistent with several studies that consider civic or sociopolitical attitudes as a mediator or predictor of civic engagement behavior (Ahmadu et al., 2016; Crocetti et al., 2012; Hope \& Jagers, 2014; Luengo Kanacri et al., 2016). For example, Crocetti et al. (2012) studied around 400 Italians and reported attitudes as a mediator between identity and civic engagement. In this study, they conceptualized attitudes as a sense of social responsibility (Crocetti et al., 2012). Ahmadu et al. (2016) and Hope and Jagers (2014) studied Nigerians and African-Americans, respectively, and found sociopolitical attitudes and political efficacy belief as significant predictors of the level 
of civic engagement. In a study of 1,300 Chileans, Luengo Kanacri et al. (2016) found beliefs about poverty as a predictor of monetary donations.

The examination of civic attitudes and its mediating effects among MENA refugees and immigrants is a research area that remains understudied. In sum, the purpose of this study was to address these gaps in our knowledge of civic engagement among immigrants and refugees to the U.S. from MENA. The primary research questions were:

1. What factors predict civic attitudes among the target group?

2. Does attitude mediate between its potential predictors and civic engagement behavior?

\section{Method}

\section{Participants and Procedures}

Four inclusion criteria were used to identify participants for this study: a refugee or immigrant from MENA; a U.S. citizen or permanent resident; having the ability to read English; and age 18 or above. Because of the inaccessibility of this population sub-group, non-probability convenience sampling was applied. The researcher recruited individuals from Facebook pages created for the target population as well as from locations such as restaurants and ethnic grocery stores that this group was more likely to visit. These locations were in the capital city of an Eastern U.S. state. Before posting flyers, permission was obtained from the managers at these venues. For those recruited through Facebook, an online version of the survey was offered. The first recruitment phase was followed with two reminders in subsequent weeks. Those recruited in groceries or restaurants filled out the paper version in the location. The researcher had a table and sat in the location in three different time slots for the purpose of survey administration. The researcher obtained Institutional Review Board (IRB) approval to ensure ethical considerations. Those eligible and interested in participating were given/presented a Study Information Sheet summarizing the purpose and requirements of the study.

\section{Measures}

The survey was in English language and included four sections: screening questions; demographics; civic attitudes; and level of civic engagement (behavior or involvement in civic activities). Screening questions were to check age, if the person was a U.S. citizen or permanent resident, and if they were originally from one of the 20 MENA countries.

Demographics. Five demographic variables were included for the purpose of describing the respondents. Gender was asked using three options of male, female, and other. The researcher used a closed-ended question to ask month and year of entrance to the U.S. This question was used to calculate the length of U.S. stay. Education level was assessed using six options including "less than high school" to "PhD". Health status and English language proficiency were asked using one question with five-point Likert scale from 1 (very poor) to 5 (excellent).

Civic attitudes. The researcher used six statements from existing scales (Table 3) to measure civic attitudes in terms of self-efficacy and social responsibility (Bobek et al., 2009; Doolittle \& Faul, 2013; Zaff et al., 2010). Example items were "I can make a difference in my community" (Bobek et al., 2009, p. 620) and "It is important to make 
sure all people are treated fairly" (Zaff et al., 2010, p. 742). The items were approved in terms of face and content validity. For this purpose, the researcher sought the feedback of five colleagues who are experts in the field of civic engagement and were familiar with MENA countries. A Cronbach's alpha of 0.91 was found for these items, indicating strong internal consistency. Response choices were a five-point Likert scale, with the options from 1 (strongly disagree) to 5 (strongly agree). A summary score was computed for each respondent. Higher scores indicated more positive civic engagement attitudes.

Civic engagement. Civic involvement during the prior 12 months was examined using seven statements derived from existing scales (Doolittle \& Faul, 2013; Finlay et al., 2011; Keeter et al., 2003; Zaff et al., 2010). Table 4 presents the statements. These examined different dimensions of civic engagement including volunteering, donating money, helping neighbors, community problem-solving, membership in organizations, staying informed about the community, and participating in events. If a respondent was involved in volunteering, one additional question was asked to investigate the area of volunteering with response options including educational programs, health programs, homeless services, etc. (Keeter et al., 2003). Table 5 shows the areas of volunteering included in this study. "How often have you helped out your neighbors?" (Zaff et al., 2010) and "How often have you donated money to groups?" (Keeter et al., 2003) were some sample questions. The researcher consulted the same group of experts to confirm face and content validity of this section. Strong internal consistency was found (Cronbach's alpha of 0.84). A five-point Likert scale with responses from 1 (never) to 5 (always) was used. A summary score was computed for each respondent indicating the level of civic engagement during the last 12 months. Greater scores reflected higher levels of civic engagement.

\section{Data Analysis}

For analysis, the researcher ran descriptive statistics for each variable depending on its level of measurement. To examine the first research question, multiple linear regression analysis was conducted using gender, U.S. length of stay, language proficiency, and health status as potential predictors with civic attitudes as a dependent variable. To investigate the mediation effect for the second question, the researcher implemented three linear regression models. The first model included the primary independent variable (gender, health status, language proficiency, or length of stay) and the mediator (civic attitudes). The second included the primary independent variables and civic engagement as the dependent measure. The third regression model included civic attitudes and civic engagement while controlling for the primary independent variables. To confirm the mediation effect, in the first two models, the association of variables must be significant. In addition, in the third model, not only the association of the mediator and the dependent variable must stay significant, but also the relationship of the primary independent variable and the dependent one must significantly decrease. Figure 1 illustrates the relevant conceptual model.

\section{Results}

\section{Participants}

One hundred and forty-five MENA immigrants and refugees participated in this study. Facebook pages used for recruitment had hundreds to thousands of members. It is not possible to estimate what percentage of members visited the posted messages. 
Therefore, it is not easy to determine the response rate in this type of recruitment. Ninety-eight people completed the online survey, just over two-thirds $(67.6 \%)$ of all respondents. For in-person recruitment, the researcher provided 100 copies of the survey. Forty-seven, $32.4 \%$ of respondents, completed paper-based surveys. As the number of people available was not possible to determine, the response rate could not be calculated in this kind of recruitment. Respondents were from 12 countries. Iran $(n=52,35.9 \%)$, Tunisia $(n=21,14.5 \%)$, Jordan $(n=16,11.0 \%)$, and Egypt $(n=15$, $10.3 \%$ ) had the highest number of participants. Table 1 presents the number and percentages of participants by country of origin.

Table 1. Descriptive Information of Participants $(n=145)$

\begin{tabular}{lr}
\hline Characteristic & $\mathrm{n}(\%)$ \\
\hline Country of origin (n=145) & \\
Algeria & $4(2.8 \%)$ \\
Egypt & $15(10.3 \%)$ \\
Iran & $52(35.9 \%)$ \\
Iraq & $7(4.8 \%)$ \\
Jordan & $16(11.0 \%)$ \\
Lebanon & $3(2.1 \%)$ \\
Morocco & $6(4.1 \%)$ \\
State of Palestine & $9(6.2 \%)$ \\
Sudan & $3(2.1 \%)$ \\
Syria & $6(4.1 \%)$ \\
Tunisia & $21(14.5 \%)$ \\
Yemen & $3(2.1 \%)$ \\
Residency status (n=145) & \\
U.S. citizen or permanent resident entered as a non-refugee & $119(82.1 \%)$ \\
U.S. citizen or permanent resident entered as a refugee & $26(17.9 \%)$ \\
Gender (n=138) & \\
Male & $90(65.2 \%)$ \\
Education (n=139) & \\
Less than high school & $1(0.7 \%)$ \\
High school/GED & $11(7.9 \%)$ \\
Some college & $23(16.5 \%)$ \\
Bachelor degree & $51(36.7 \%)$ \\
Master degree & $33(23.7 \%)$ \\
PhD & $20(14.4 \%)$ \\
Health status* (n=140) & \\
Excellent & $56(40.0 \%)$ \\
Good & $61(43.6 \%)$ \\
Fair & $21(15.0 \%)$ \\
Poor & $2(1.4 \%)$ \\
English language proficiency** (n=139) & \\
Excellent & $68(48.9 \%)$ \\
Good & $55(39.6 \%)$ \\
Fair & $15(10.8 \%)$ \\
Poor & $1(0.7 \%)$ \\
\hline *Range 2-5, Mean (SD) 4.2 $(0.8) ; * *$ Range 2-5, Mean (SD) & $4.4(0.7)$ \\
& \\
\hline &
\end{tabular}


Table 2. Descriptive Information of Participants and Key Variables $(n=145)$

\begin{tabular}{lll}
\hline & Range & Mean (SD) \\
\hline Age (n=145) & $19-66$ & $37.6(10.2)$ \\
Length of Stay (months) $(\mathrm{n}=135)$ & $4-608$ & $174.5(136.8)$ \\
Civic Attitudes ( $\mathrm{n}=140)$ & $6-30$ & $26.0(4.8)$ \\
Civic Engagement (n=132) & $11-35$ & $22.7(5.7)$ \\
\hline
\end{tabular}

Twenty-six (17.9\%) participants came to the U.S. as refugees and the others $(n=119,82.1 \%)$ entered as immigrants. On average, respondents were 37.6 years of age. Ninety (65.2\%) participants were male. On average, the length of stay in the U.S. was 174.5 months (nearly 14.5 years). In terms of education level, having an undergraduate degree or higher was the most common (74.8\%). The majority of respondents reported a high level of English language proficiency $(88.5 \%)$ as well as good or excellent health status (83.6\%). Demographic information of participants and a profile of the study's key variables are presented in Tables 1 and 2.

\section{Civic Attitudes}

As shown in Table 2, very positive civic attitudes were reported by study participants $(n=140 ; M=26.0 ; S D=4.8)$. The mean $(\mathrm{M})$, frequency, and standard deviation (SD) of each item are presented in Table 3. The items have a mean between 4.1 and 4.5 . Nearly $80 \%$ of participants endorsed every item. Conducting a t-test $(t(131)$ $=-0.9, p=0.37)$, no significant differences in civic attitudes were found between males $(n=86, M=26.1, S D=4.9)$ and females $(n=47, M=26.8, S D=2.9)$, as well as between those who entered the U.S. as a refugee $(n=25, M=25.5, S D=5.9)$ and those who entered as a non-refugee $(n=115, M=26.1, S D=4.5 ; t(138)=0.6, p=0.56)$. All assumptions required for conducting the t-test were met.

\section{Civic Engagement}

As indicated in Table 2, participants reported engagement in various civic activities $(n=132, M=22.7, S D=5.7)$. The researcher conducted a t-test and found no significant differences in civic engagement between men $(n=83, M=22.4, S D=6.0)$ and women $(n=46, M=23.4, S D=5.2 ; t(127)=-0.9, p=0.38)$, as well as between those who entered the U.S. as a refugee $(n=23, M=24.8, S D=6.8)$ and those entered as a nonrefugee $(n=109, M=22.2, S D=5.4 ; t(130)=-2.0, p=0.05)$. The descriptive statistics of each item including mean, SD, and frequency are presented in Table 4. The items have a mean between 2.6 and 3.8. The most popular area of civic engagement was to stay informed about the community followed by helping neighbors. Ninety-five respondents reported volunteering in the community during the last 12 months. Most of these volunteering experiences were in educational programs $(n=37,38.9 \%)$, services for homeless and economically disadvantaged people $(n=36,37.9 \%)$, children's programs $(n=32,33.7 \%)$ followed by youth programs $(n=26,27.4 \%)$, health programs $(n=24,25.3 \%)$, international charities $(n=23,24.2 \%)$, religious groups $(n=23,24.2 \%)$, and refugee and immigrant services $(n=21,22.1 \%)$. Programs for elderly people $(n=12,12.6 \%)$, environmental programs $(n=9,9.5 \%)$, and labor unions $(n=5,5.3 \%)$ were the least popular volunteering areas. See Table 5 for more details. 
Table 3. Civic Attitudes

\begin{tabular}{|c|c|c|c|c|c|c|c|}
\hline \multirow[b]{2}{*}{ Item } & \multicolumn{5}{|c|}{ Frequency $(\%)$} & \multirow[b]{2}{*}{$\mathrm{M}(\mathrm{SD})$} & \multirow[b]{2}{*}{$\mathrm{n}$} \\
\hline & Strongly disagree & Disagree & $\begin{array}{c}\text { Neither agree } \\
\text { nor disagree }\end{array}$ & Agree & Strongly agree & & \\
\hline It is important "to make sure all people are treated fairly"* & $6(4.2 \%)$ & --- & $4(2.8 \%)$ & $35(24.3 \%)$ & $99(68.8 \%)$ & $4.5(0.9)$ & 144 \\
\hline It is important "to make the world a better place to live in"* & $8(5.5 \%)$ & $1(0.7 \%)$ & --- & $35(24.1 \%)$ & $101(69.7 \%)$ & $4.5(1.0)$ & 145 \\
\hline It is important to help out at your local community* & $5(3.4 \%)$ & $2(1.4 \%)$ & $7(4.8 \%)$ & $52(35.9 \%)$ & $79(54.5 \%)$ & $4.4(0.9)$ & 145 \\
\hline $\begin{array}{l}\text { "I often think about doing things so that people in the future can } \\
\text { have things better"* }\end{array}$ & $5(3.5 \%)$ & $1(0.7 \%)$ & $9(6.2 \%)$ & $54(37.5 \%)$ & $75(52.1 \%)$ & $4.3(0.9)$ & 144 \\
\hline "I can make a difference in my community"** & $5(3.5 \%)$ & $2(1.4 \%)$ & $13(9.0 \%)$ & $63(43.8 \%)$ & $61(42.4 \%)$ & $4.2(0.9)$ & 144 \\
\hline "I have a responsibility to help the poor and the hungry"*** & $9(6.3 \%)$ & $4(2.8 \%)$ & $16(11.3 \%)$ & $49(34.5 \%)$ & $64(45.1 \%)$ & $4.1(1.1)$ & 142 \\
\hline
\end{tabular}

Table 4. Civic Engagement

\begin{tabular}{|c|c|c|c|c|c|c|c|}
\hline \multirow[b]{2}{*}{ Item } & \multicolumn{5}{|c|}{ Frequency } & \multirow[b]{2}{*}{$\mathrm{M}(\mathrm{SD})$} & \multirow[b]{2}{*}{$n$} \\
\hline & Never & Rarely & Sometimes & Often & Always & & \\
\hline $\begin{array}{l}\text { How often have you stayed informed of what is going on in your } \\
\text { community?* }\end{array}$ & $3(2.1 \%)$ & $13(9.3 \%)$ & $31(22.1 \%)$ & $52(37.1 \%)$ & $41(29.3 \%)$ & $3.8(1.0)$ & 140 \\
\hline How often have you helped out your neighbors?** & $3(2.1 \%)$ & $18(12.9 \%)$ & $55(39.3 \%)$ & $34(24.3 \%)$ & $30(21.4 \%)$ & $3.5(1.0)$ & 140 \\
\hline How often have you donated money to groups?*** & $5(3.6 \%)$ & $22(15.9 \%)$ & $53(38.4 \%)$ & $25(18.1 \%)$ & $33(23.9 \%)$ & $3.4(1.1)$ & 138 \\
\hline How often have you been a member of any organization?*** & $18(12.9 \%)$ & $24(17.1 \%)$ & $46(32.9 \%)$ & $22(15.7 \%)$ & $30(21.4 \%)$ & $3.2(1.3)$ & 140 \\
\hline $\begin{array}{l}\text { How often have you "participated in events such as meetings, } \\
\text { celebrations, or activities in the community?"**** }\end{array}$ & $9(6.5 \%)$ & $22(15.9 \%)$ & $58(42.0 \%)$ & $34(24.6 \%)$ & $15(10.9 \%)$ & $3.2(1.0)$ & 138 \\
\hline $\begin{array}{l}\text { How often "have you worked together informally with someone } \\
\text { or some group to solve a problem in the community where you } \\
\text { live?"*** }\end{array}$ & $11(7.9 \%)$ & $20(14.4 \%)$ & $62(44.6 \%)$ & $28(20.1 \%)$ & $18(12.9 \%)$ & $3.2(1.1)$ & 139 \\
\hline $\begin{array}{l}\text { How often have you volunteered in community services for no } \\
\text { pay?*** }\end{array}$ & $47(34.3 \%)$ & $13(9.5 \%)$ & $40(29.2 \%)$ & $23(16.8 \%)$ & $14(10.2 \%)$ & $2.6(1.4)$ & 137 \\
\hline
\end{tabular}

*(Doolittle \& Faul, 2013)**(Zaff et al., 2010) $* * *($ Keeter et al., 2003) ****(Finlay et al., 2011, p. 1732) 
Table 5. Volunteering by Areas (n (\%))

\begin{tabular}{lc} 
Educational programs & $37(38.9 \%)$ \\
$\begin{array}{l}\text { Services for homelessness and economically } \\
\text { disadvantaged people }\end{array}$ & $36(37.9 \%)$ \\
Children programs & \\
Youth programs & $32(33.7 \%)$ \\
Health programs & $26(27.4 \%)$ \\
International charities & $24(25.3 \%)$ \\
Religious groups & $23(24.2 \%)$ \\
Refugees and immigrants services & $23(24.2 \%)$ \\
Programs for elderly people & $21(22.1 \%)$ \\
Environmental programs & $12(12.6 \%)$ \\
Labor unions & $9(9.5 \%)$ \\
\hline
\end{tabular}

\section{Factors Associated with Civic Attitudes}

The first research question examined factors predicting civic attitudes. Multiple linear regression was conducted to investigate the impact of U.S. length of stay, health status, language proficiency, and gender (as a control variable) on attitudes. The assumptions of this test including the variables' level of measurement, normality of dependent variable, independence of observations, multicollinearity, homoscedasticity, linearity, and no-outlier were met. Bivariate correlation was checked using Pearson correlation (Table 6). Based on this test, health status $(r(135)=0.3, p<0.01)$ and English language proficiency $(r(134)=0.3, p<0.01)$ were significantly correlated with level of civic attitudes. Better health and greater English proficiency were associated with more positive civic attitudes. That is, those who were healthier or more proficient in English language had stronger civic attitudes.

Table 6. Pearson Correlation Matrix

\begin{tabular}{|c|c|c|c|c|c|c|}
\hline & 1 & 2 & 3 & 4 & 5 & 6 \\
\hline 1. Gender ${ }^{\mathrm{a}}$ & 1.0 & 0.0 & -0.1 & $-0.2 *$ & 0.1 & 0.1 \\
\hline 2. Length of stay & & 1.0 & 0.0 & 0.1 & 0.0 & 0.1 \\
\hline 3. Health & & & 1.0 & $0.4 * *$ & $0.3 * *$ & $0.2 *$ \\
\hline 4. English language & & & & 1.0 & $0.3 * *$ & 0.1 \\
\hline 5. Civic attitude & & & & & 1.0 & $0.4 * *$ \\
\hline 6. Civic engagement & & & & & & 1.0 \\
\hline
\end{tabular}

The regression model was significant $(F(4,122)=5.2, p<0.01)$. This model explained $15 \%$ of the variance in civic attitudes with these four variables $\left(R=0.4, R^{2}\right.$ $=0.15)$. Health status $(B=1.1, \beta=0.2, S E=0.5, t=2.0, p<0.05)$ and English language proficiency $(B=1.7, \beta=0.3, S E=0.6, t=2.9, p<0.01)$ were significant factors. Unstandardized coefficients indicated that for a one unit improvement in health status or a one unit increase in language proficiency, attitudes toward civic engagement significantly improved by 1.1 or 1.7 units, respectively (Table 7). 
Table 7. Regression Analysis

\begin{tabular}{lccccc}
\hline & B & Std. Error & Beta & t & Sig. \\
\hline Length of Stay & 0.0 & 0.0 & 0.0 & 0.3 & 0.80 \\
Health Status & 1.1 & 0.5 & 0.2 & 2.0 & $<0.05$ \\
English language proficiency & 1.7 & 0.6 & 0.3 & 2.9 & $<0.01$ \\
Gender & 1.2 & 0.8 & 0.1 & 1.5 & 0.10 \\
\hline
\end{tabular}

\section{Mediation Effect of Civic Attitudes}

In order to examine the second research question, the mediation effect of civic attitudes was analyzed using three linear regression models. First, Pearson correlation was checked. According to this test (Table 6 ), health status was significantly associated with both civic attitudes $(r(135)=0.3, p<0.01)$ and civic engagement $(r(131)=0.2, p$ $<0.05$ ). Other independent variables (i.e., language proficiency and U.S. length of stay) were not significantly correlated with civic engagement. Therefore, these could not be examined in mediation analysis. Civic attitudes and engagement were also significantly correlated with each other $(r(129)=0.4, p<0.01)$. Thus, the mediation effect of civic attitudes between health status and civic engagement was examined.

First, bivariate regression analysis was conducted to see if health status predicted civic attitudes. Including health status as the only independent variable, the regression model was significant $(F(1,133)=9.3, p<0.01)$. Health status explained $7 \%$ of variability in civic attitudes $\left(R=0.3, R^{2}=0.07\right)$. For a one unit increase in health status, civic attitudes improved by 1.5 units $(\beta=0.3, S E=0.5, t=3.1, p<0.01)$. The second regression model was also significant $(F(1,129)=5.5, p<0.05)$ with health status explaining $4 \%$ of the variance in civic engagement $\left(R=0.2, R^{2}=0.04\right)$. In this model, a one unit increase in health status led to a 1.5 unit improvement in civic engagement $(\beta=0.2, S E=0.7, t=2.3, p<0.05)$. Finally, multiple regression analysis was conducted with civic attitudes as an independent variable, controlling for health status, and civic engagement as the dependent variable. This regression model was also significant $(F(2$, $125)=11.8, p<0.01)$. These two variables explained $16 \%$ of the variance in civic engagement $(R=0.4)$. Health status was no longer a significant factor $(p>0.05)$ but attitudes were significant; for each one unit increase in civic attitude, engagement improved 0.4 units $(\beta=0.3, S E=0.1, t=3.8, p<0.01)$. This analysis demonstrated that civic attitudes mediate between health status and civic engagement. Statistical assumptions for all regression models were met. Figure 1 illustrates the standardized regression coefficients. 
Figure 1. The Mediation Model

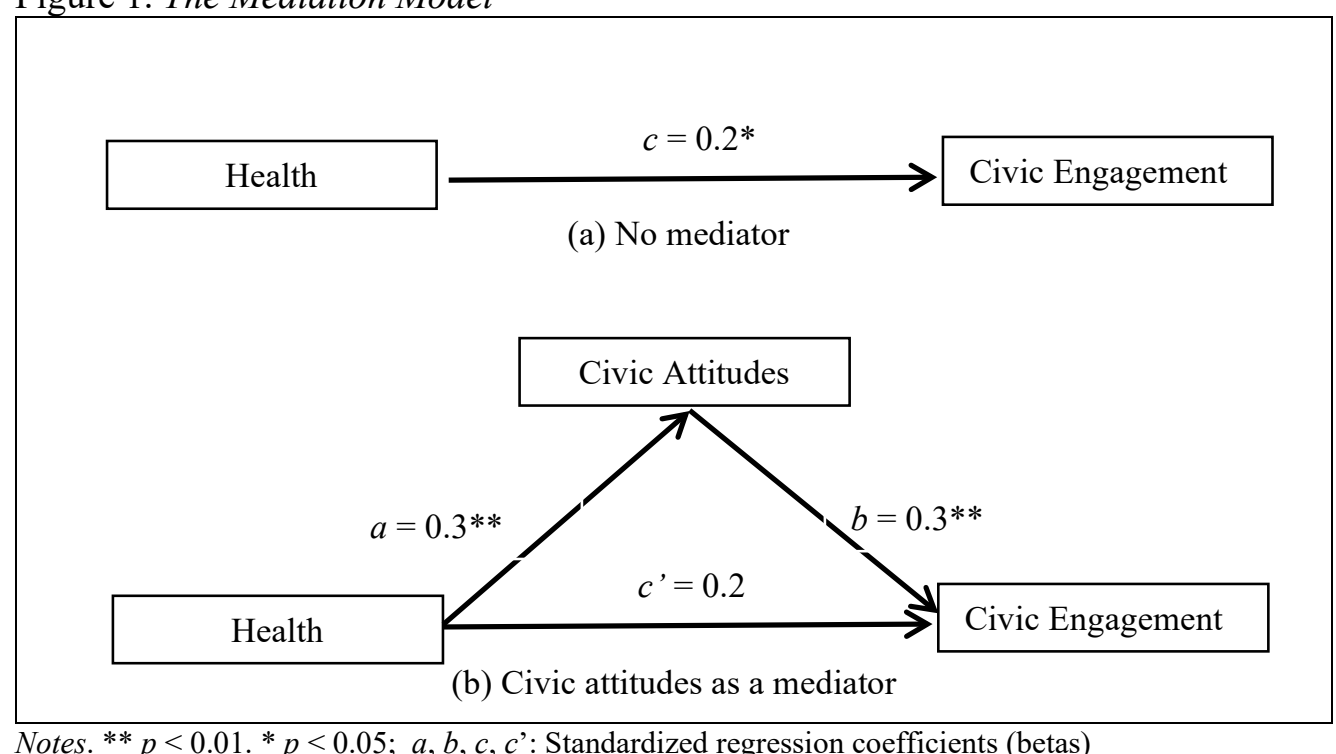

\section{Discussion}

This study examined factors predicting civic attitudes as well as the mediation effect of attitudes between those factors and civic engagement. Descriptive statistics demonstrated strong feelings of social responsibility toward community members among the target group, which is consistent with other studies of immigrants in the U.S. (Jensen, 2008; Makki Alamdari et al., 2016; Makki Alamdari \& Bishop, 2020). In addition, the participants reported active engagement, especially in terms of staying informed about the community, helping neighbors, and donating money. Two-thirds of respondents had volunteering experiences during the previous 12 months. This is in line with other studies on immigrants' civic engagement in the U.S. (Abu-Ras, 2013; Jensen, 2008; Makki Alamdari, 2017; Read, 2014; Tucker \& Santiago, 2013), which reported active involvement. This study shows that refugees and immigrants from the MENA region are not isolated and have high capability to contribute to their communities.

The results of the study showed that the length of stay was not a significant predictor of civic attitudes. More studies should examine this factor in the future. In addition, gender did not predict civic attitudes, which is consistent with the study of Handy and Greenspan (2009) indicating no significant association between gender and volunteering among immigrants in Canada. However, the study found health status and English language proficiency as significant factors predicting civic attitudes among MENA refugees and immigrants. That is, those who were more competent in the English language and those with better health status had more positive attitudes toward civic engagement. Immigrants and refugees with higher levels of language proficiency are more likely to communicate and learn about the host communities. This is consistent with the existing literature. Stepick et al. (2001) studied the Haitian immigrant community in Florida using focus groups and interviews and reported language difficulties as a barrier to civic participation. Similarly, Boyd (2009) and Van Londen et al. (2007) examined immigrants in Canada and the Netherlands and confirmed the importance of language skills in civic and political participation. 
Furthermore, the direct and positive effect of self-rated health on civic and political participation was acknowledged in the existing literature conducted in the UK, Australia, and the U.S. (Burden et al., 2017; Ding et al., 2015; Emerson et al., 2014).

In line with existing literature, this study supported the finding that civic attitudes predict civic engagement. Gastil and Xenos (2010) studied approximately 3,000 Americans and found attitudes about one's efficacy in political areas were a predictor of political participation. Luengo Kanacri et al. (2016) examined 1,300 people in Chile and found beliefs regarding poverty as a significant factor predicting financial donation. These findings suggest that improving civic attitudes can lead to higher levels of participation in civic activities. With this in mind, education and awareness-raising are critical to improve attitudes. Based on a representative sample of Black youth in the U.S., Hope and Jagers (2014) reported that formal and informal civic education can significantly act as a moderator and strengthen the association between sociopolitical attitudes and civic engagement. Community agencies can educate MENA refugees and immigrants regarding their activities, participation opportunities, and benefits of civic engagement.

The findings of this study have a number of implications for social work practice. Augmenting their civic attitudes and consequently their civic engagement, refugees and immigrants can experience better health, greater life satisfaction, stronger social networks, more effective integration in the new community, as well as address their feelings of isolation and loneliness (Gele \& Harsløf, 2012; Weng \& Lee, 2016). This will also improve communities through increasing human capital, diversity, democracy, and the quality of public service (Handy \& Greenspan, 2009; Makki Alamdari \& Jalaiepour, 2012; Tucker \& Santiago, 2013). The social work profession emphasizes such individual and societal improvements as its core values (National Association of Social Workers, 2017).

Improving English language skills can help enhance the target population's civic attitudes. In this case, especially for refugees, providing English as a Second Language classes through resettlement agencies or religious institutions is beneficial. Improving the accessibility and effectiveness of such classes for the target population is recommended (Steele, 2017). In addition, if possible, marketing regarding community events or volunteer opportunities can be undertaken through ethnic social networks, so that immigrants and refugees can communicate around these topics in their own language. Finally, having civic learning programs or flyers in refugees and immigrants' native language can aid in developing stronger civic attitudes.

Moreover, no mediation effect of civic attitudes was found between factors of English language proficiency or length of stay and civic engagement. However, the results indicated civic attitudes as a mediator between health status and civic engagement. Improving health among immigrants and refugees through culturallyappropriate practice and support groups, health information provision, counselling, and evidence-based policies can enhance the level of civic engagement through strengthening civic attitudes (de Bocanegra et al., 2018; Shishehgar et al., 2017). In other words, health status not only directly predicts civic attitudes, but also indirectly influences the level of civic engagement. This has important implications. At the policy and program level, providing diverse, equitable, and affordable health services that meet the health needs of immigrants and refugees is fundamental (Burden et al., 2017; Newbold \& McKeary, 2017). Additionally, community agencies and organizations that 
conduct civic participation activities can offer specific programs that, in addition to the general purposes, render some incentives or benefits for those who may experience health issues. For example, if there is a community event, the convener agency can have a booth or a table to offer health-related information or basic services such as blood pressure examination. This might encourage those with lower health status to participate in programs. More studies are needed to investigate what kinds of community programs might be of interest for those immigrants and refugees with lower health status.

This study has several limitations. The assumption of the researcher in this study was that attitudes form and influence civic engagement. However, it is critical to acknowledge that the reverse direction is possible as well. That is, higher levels of civic engagement can improve civic attitudes through exposing individuals to diverse populations (O'Leary, 2014; Pascarella \& Terenzini, 2005). Immigrants tend to have a higher health status upon arrival in the host country, which declines over time during their stay because of negative acculturation effects (Ablow Measelle et al., 2019; Gorman et al., 2010). This study did not examine the impact of this declining health on civic attitudes and engagement. Using a longitudinal design, future studies can address this limitation. Further, many potential factors were not investigated. For example, factors such as age, religious and cultural identity, family income, education, and whether the members of the target population hope to return home one day (Choi, 2003; Handy \& Greenspan, 2009; Jensen, 2008; Read, 2014; Tucker \& Santiago, 2013) can be considered in future studies. This study examined many forms of civic engagement such as volunteering, community problem-solving, and monetary donation under one broad label of civic engagement. For future studies, it could be more beneficial to look at each of these forms individually. In terms of validity, confirming other forms such as construct and factor validity could increase rigor. Using self-report measures of health status and English language proficiency was also an issue in this study. One constraint was social desirability bias. That is, respondents might have answered in a way that is desired by others. Participants were recruited mainly from Facebook pages or convenient locations. This posed sampling bias and limited the generalizability of the findings as this sample was not representative. Most participants had a high levels of language proficiency, education, and health status. There were also some MENA countries that were not represented in this study's participants. For future studies, recruiting more diverse participants is recommended.

\section{Conclusion}

This study contributes to the existing literature by examining civic attitudes and engagement of an understudied group of immigrants and refugees. English language proficiency and health status were found to be significant factors for improving civic attitudes. Health status was also found as a critical factor indirectly increasing the level of civic engagement through enhancing attitudes. These findings are useful to enhance resettlement programs, health policies, and services as relevant to this group as well as civic events in a way to advance civic attitudes and engagement of MENA refugees and immigrants. Promoting civic engagement of this group could help to counter antiMuslim viewpoints that are common in the U.S. 


\section{References}

Ablow Measelle, E., McClure, H. H., Snodgrass, J. J., Martinez Jr, C. R., Jiménez, R., \& Isiordia, L. (2019). Climbing the ladder of decline: Income and acculturation associated with chronic inflammation among Mexican immigrants. American Journal of Human Biology, 31(e23271), 1-10. https://doi.org/10.1002/ajhb.23271

Abu-Ras, W. (2013). American Muslim physicians' public role post-9/11 and minority community empowerment: Serving the underserved. Journal of Immigrant \& Refugee Studies, 11(1), 1-23. https://doi.org/10.1080/15562948.2013.759012

Adler, R. P., \& Goggin, J. (2005). What do we mean by "civic engagement"? Journal of Transformative Education, 3(3), 236-253. https://doi.org/10.1177/1541344605276792

Ahmadu, T. S., Don, M. Y., \& Hamzat, I. H. (2016). The effect of political efficacy and citizenship norms on civic engagement in Nigeria: Students' perspective. Asia Journal of Social Sciences, Arts and Humanities, 4(2), 65-77. http://www.multidisciplinaryjournals.com/wp-content/uploads/2016/03/FULLPAPER-THE-EFFECT-OF-POLITICAL-EFFICACY-AND-CITIZENSHIPNORMS.pdf

Aroian, K. J., Kaskiri, E. A., \& Templin, T. N. (2008). Psychometric evaluation of the Arabic language version of the Demands of Immigration Scale. International Journal of Testing, 8(1), 2-13. https://doi.org/10.1080/15305050701808490

Bishop, C. M. \& Makki Alamdari, S. (2018). The impact of paternal involvement and United States stay length on Latino youth's depressive symptoms. Perspectives on Social Work Journal, 14(2), 2-16. https://doi.org/10.7912/ja6w-em36

Bobek, D., Zaff, J., Li, Y., \& Lerner, R. M. (2009). Cognitive, emotional, and behavioral components of civic action: Towards an integrated measure of civic engagement. Journal of Applied Developmental Psychology, 30(5), 615-627. https://doi.org/10.1016/j.appdev.2009.07.005

Boyd, M. (2009, October). Official language proficiency and the civic participation of immigrants. Paper presented at the Metropolis Language Matters Symposium, Ottawa, Canada.

Brown, A. G., Hudson, L. B., Chui, K., Metayer, N., Lebron-Torres, N., Seguin, R. A., \& Folta, S. C. (2017). Improving heart health among Black/African American women using civic engagement: A pilot study. BMC Public Health, 17(1), 112125. https://doi.org/10.1186/s12889-016-3964-2

Burden, B. C., Fletcher, J. M., Herd, P., Moynihan, D. P., \& Jones, B. M. (2017). How different forms of health matter to political participation. Journal of Politics, 79(1), 166-178. https://doi.org/10.1086/687536

Chan, W. Y. (2011). An exploration of Asian American college students' civic engagement. Asian American Journal of Psychology, 2(3), 197-204. https://doi.org/10.1037/a0024675

Chandra, A., Miller, C. E., Acosta, J. D., Weilant, S., Trujillo, M., \& Plough, A. (2016). Drivers of health as a shared value: Mindset, expectations, sense of community, and civic engagement. Health Affairs, 35(11), 1959-1963. https://doi.org/10.1377/hlthaff.2016.0603 
Checkoway, B. (2009). Youth civic engagement for dialogue and diversity at the metropolitan level. The Foundation Review, 1(2), 41-50.

https://doi.org/10.4087/foundationreview-d-09-00015

Choi, L. H. (2003). Factors affecting volunteerism among older adults. Journal of Applied Gerontology, 22(2), 179-196. https://doi.org/10.1177/0733464803022002001

Crocetti, E., Jahromi, P., \& Meeus, W. (2012). Identity and civic engagement in adolescence. Journal of Adolescence, 35(3), 521-532. https://doi.org/10.1016/j.adolescence.2011.08.003

Dabelko-Schoeny, H., Anderson, K. A., \& Spinks, K. (2010). Civic engagement for older adults with functional limitations: Piloting an intervention for adult day health participants. Gerontologist, 50(5), 694-701. https://doi.org/10.1093/geront/gnq019

De Bocanegra, H. T., Carter-Pokras, O., Ingleby, J. D., Pottie, K., Tchangalova, N., Allen, S. I., ... \& Hidalgo, B. (2018). Addressing refugee health through evidencebased policies: A case study. Annals of Epidemiology, 28(6), 411-419. https://doi.org/10.1016/j.annepidem.2017.05.010

Department of Homeland Security. (2019). 2017 Yearbook of immigration statistics. https://www.dhs.gov/immigration-statistics/yearbook/2017

Ding, N., Berry, H. L., \& O'Brien, L. V. (2015). One-year reciprocal relationship between community participation and mental wellbeing in Australia: A panel analysis. Social Science \& Medicine, 128, 246-254. https://doi.org/10.1016/j.socscimed.2015.01.022

Doolittle, A., \& Faul, A. C. (2013). Civic Engagement Scale. SAGE Open, 3(3), 1-7.

Emami, J. (2018). Gender, group solidarity, group conflict, and Iranian-American civic engagement (Doctoral dissertation, George Mason University).

Emerson, E., Hatton, C., Robertson, J., \& Baines, S. (2014). Perceptions of neighbourhood quality, social and civic participation and the self-rated health of British adults with intellectual disability: Cross sectional study. BMC Public Health, 14(1), 1-8. https://doi.org/10.1186/1471-2458-14-1252

Finlay, A. K., Flanagan, C., \& Wray-Lake, L. (2011). Civic engagement patterns and transitions over 8 years: The AmeriCorps national study. Developmental Psychology, 47(6), 1728-1743. https://doi.org/10.1037/a0025360

Gastil, J., \& Xenos, M. (2010). Of attitudes and engagement: Clarifying the reciprocal relationship between civic attitudes and political participation. Journal of Communication, 60(2), 318-343. https://doi.org/10.1111/j.14602466.2010.01484.X

Gele, A. A., \& Harsløf, I. (2012). Barriers and facilitators to civic engagement among elderly African immigrants in Oslo. Journal of Immigrant and Minority Health, 14(1), 166-174. https://doi.org/10.1007/s10903-010-9423-8

Gidengil, E., \& Stolle, D. (2009). The role of social networks in immigrant women's political incorporation. International Migration Review, 43(4), 727-763. https://doi.org/10.1111/j.1747-7379.2009.00783.x 
Gorman, B. K., Read, J. G., \& Krueger, P. M. (2010). Gender, acculturation, and health among Mexican Americans. Journal of Health and Social Behavior, 51(4), 440-457. https://doi.org/10.1177/0022146510386792

Handy, F., \& Greenspan, I. (2009). Immigrant volunteering: A stepping stone to integration? Nonprofit and Voluntary Sector Quarterly, 38(6), 956-982. https://doi.org/10.1177/0899764008324455

Hope, E. C., \& Jagers, R. J. (2014). The role of sociopolitical attitudes and civic education in the civic engagement of Black youth. Journal of Research on Adolescence, 24(3), 460-470. https://doi.org/10.1111/jora.12117

Jensen, L. A. (2008). Immigrants' cultural identities as sources of civic engagement. Applied Development Science, 12(2), 74-83. https://doi.org/10.1080/10888690801997069

Luengo Kanacri, B. P., González, R., Valdenegro, D., Jiménez-Moya, G., Saavedra, P., Mora, E. A., ... \& Pastorelli, C. (2016). Civic engagement and giving behaviors: The role of empathy and beliefs about poverty. Journal of Social Psychology, 156(3), 256-271. https://doi.org/10.1080/00224545.2016.1148006

Keeter, S., Jenkins, K., Zukin, C., \& Andolina, M. (2003, March). Three core measures of community-based civic engagement: Evidence from the youth civic engagement indicators project. Child Trends Conference on Indicators of Positive Development, Washington, DC. https://www.childtrends.org/wpcontent/uploads/2013/05/Child_Trends-2003 03 12_PD_PDConfKJZA.pdf

Makki Alamdari, S., \& Jalaiepour, H. (2012). A comparative content analysis of $2^{\text {nd }}$ and $3^{\text {rd }}$ grades of elementary school's Persian literature course books of 1967 and 2008 with regard to civil behavior elements. Journal of Curriculum Studies, 6(23), 36-55.

Makki Alamdari, S., Alhajri, W., \& Kim, H. (2016, November). Civic engagement among Middle Eastern and North African refugees and immigrants. CSWE 2016 Annual Program Meeting, Atlanta, GA.

Makki Alamdari, S. (2017, March). Improving civic engagement: A strength-based strategy to address post-resettlement challenges. Paper presented at Refugee Provider Conference,. Canyon, TX: West Texas A\&M University.

Makki Alamdari, S. (under review). Resilience factors among adults affected by mass conflict: Recommendations for researchers. Journal of Social Inclusion.

Makki Alamdari, S. \& Bishop, C. (2020). Civic engagement among Iranians in the United States. Journal of Muslim Philanthropy \& Civil Society, 4(1), 27-54.

National Association of Social Workers. (2017). Code of ethics. https://www.socialworkers.org/about/ethics/code-of-ethics/code-of-ethics-english

Newbold, B., \& McKeary, M. (2017). Investigating the diversity of Canada's refugee population and its health implications: Does one size fit all? International Journal of Migration, Health and Social Care, 13(2), 145-156.

https://doi.org/10.1108/ijmhsc-02-2015-0007 
O'Leary, L. S. (2014). Civic engagement in college students: Connections between involvement and attitudes. New Directions for Institutional Research, 2014(162), 55-65. https://doi.org/10.1002/ir.20077

Office of the High Commissioner for Human Rights. (2019). Middle East and North Africa Region. https://www.ohchr.org/EN/Countries/MENARegion/Pages/MenaRegionIndex.asp $\underline{\mathrm{X}}$

Pascarella, E. T., \& Terenzini, P. T. (2005). How college affects students: A third decade of research. San Francisco, CA: Jossey-Bass. https://doi.org/10.14426/jsaa.v2i2.70

Pew Research Center. (2015). The future of world religions: Population growth projections, 2010-2050. https://www.pewforum.org/2015/04/02/middle-eastnorth-africa/

Pieloch, K. A., McCullough, M. B., \& Marks, A. K. (2016). Resilience of children with refugee statuses: A research review. Canadian Psychology/psychologie canadienne, 57(4), 330-339. https://doi.org/10.1037/cap0000073

Putnam, R. D. (1995). Bowling alone: America's declining social capital. Journal of Democracy, 6(1), 65-78. https://doi.org/10.1353/jod.1995.0002

Read, J. G. (2014). Gender, religious identity, and civic engagement among Arab Muslims in the United States. Sociology of Religion, 76(1), 30-48. https://doi.org/10.1093/socrel/sru042

Schwartz, S. J., Unger, J. B., Zamboanga, B. L., \& Szapocznik, J. (2010). Rethinking the concept of acculturation: Implications for theory and research. American Psychologist, 65(4), 237-251. https://doi.org/10.1037/a0019330

Shishehgar, S., Gholizadeh, L., DiGiacomo, M., Green, A., \& Davidson, P. M. (2017). Health and socio-cultural experiences of refugee women: An integrative review. Journal of Immigrant and Minority Health, 19(4), 959-973. https://doi.org/10.1007/s10903-016-0379-1

Steele, T. J. (2017). English language teaching to Syrian refugees in transit. Online Journal of English Language Teaching (TOJELT), 2(1), 40-52.

Stepick, A., Stepick, C. D., \& Kretsedemas, P. (2001). Civic engagement of Haitian immigrants and Haitian Americans in Miami-Dade County. Immigration and Ethnicity Institute, Florida International University. https://www.researchgate.net/profile/Alex_Stepick/publication/268441078_Civic Engagement of Haitian_Immigrants_and Haitian_Americans_in_MiamiDade_County/links/54ca38000cf2c70ce5219a9c.pdf

Strabac, Z., Aalberg, T., \& Valenta, M. (2014). Attitudes towards Muslim immigrants: Evidence from survey experiments across four countries. Journal of Ethnic and Migration Studies, 40(1), 100-118. https://doi.org/10.1080/1369183x.2013.831542

Sundeen, R. A., Garcia, C., \& Raskoff, S. A. (2009). Ethnicity, acculturation, and volunteering to organizations: A comparison of African Americans, Asians, 
Hispanics, and Whites. Nonprofit and Voluntary Sector Quarterly, 38(6), 929-955. https://doi.org/10.1177/0899764008322779.

Tucker, C. M., \& Santiago, A. M. (2013). The role of acculturation in the civic engagement of Latino immigrants. Advances in Social Work, 14(1), 178-205. https://doi.org/10.18060/3750

Uslaner, E. M., \& Brown, M. (2005). Inequality, trust, and civic engagement. American Politics Research, 33(6), 868-894. https://doi.org/10.1177/1532673x04271903

Van Londen, M., Phalet, K., \& Hagendoorn, L. (2007). Civic engagement and voter participation among Turkish and Moroccan minorities in Rotterdam. Journal of Ethnic and Migration Studies, 33(8), 1201-1226.

https://doi.org/10.1080/13691830701613991

Vergani, M., Johns, A., Lobo, M., \& Mansouri, F. (2017). Examining Islamic religiosity and civic engagement in Melbourne. Journal of Sociology, 53(1), 6378. https://doi.org/10.1177/1440783315621167

Voicu, M., \& Rusu, I. A. (2012). Immigrants' membership in civic associations: Why are some immigrants more active than others? International Sociology, 27(6), 788-806. https://doi.org/10.1177/0268580912452172

Weng, S. S., \& Lee, J. S. (2016). Why do immigrants and refugees give back to their communities and what can we learn from their civic engagement? VOLUNTAS: International Journal of Voluntary and Nonprofit Organizations, 27(2), 509-524. https://doi.org/10.1007/s11266-015-9636-5

World Bank. (2019). Middle East \& North Africa. https://data.worldbank.org/region/middle-east-and-north-africa

Zaff, J., Boyd, M., Li, Y., Lerner, J. V., \& Lerner, R. M. (2010). Active and engaged citizenship: Multi-group and longitudinal factorial analysis of an integrated construct of civic engagement. Journal of Youth and Adolescence, 39(7), 736-750. https://doi.org/10.1007/s10964-010-9541-6

Zarpour, M. T. (2013). Discourse and dissent in the diaspora: Civic and political lives of Iranian Americans [Doctoral dissertation, University of Maryland]. http://hdl.handle.net/1903/14216

Author note: Address correspondence to Dr. Sara Makki Alamdari, West Texas A\&M University Department of Psychology, Sociology, and Social Work: salamdari@wtamu.edu

Acknowledgements: The researcher is immensely grateful to Dr. Hea-Won Kim, Associate Professor in the Indiana University School of Social Work for her constructive and valuable comments during the planning and development of this research. The researcher would also like to thank Wafa Alhajri for her assistance with data collection. 